anaphase is unknown. The MUG observations suggest that a strong connection which is separable by the anaphase trigger can arise between elements which would never normally be joined in such a manner - that is, a connection can form within a single split kinetochore in a MUG, in a similar fashion to a connection between sister kinetochores in normal cells. This result seems to favour models in which the anaphase-separable connection is made by some distributed feature of chromatin, such as DNA catenation ${ }^{12}$, rather than models which require interactions between specific sites on the sister chromatids.
1. Dictz, R. Naturwissenschaften 56. 237-248 (1969).

2. Mazia, D., Harris, P.J. \& Bibring. T. J. hiophys. Biochem Cytol. 7, 1-20)(1960)

Brinkley, B. R. et al. Nature 336. 251-254 (1988)

4. Schlegel, R. \& Pardec, A.B. Science 232. 1264-1266 (1986).

5. Murray, A. Nature 326, 542-543(1987).

Brenner, S. Pepper. D. Berns, M.W. Tan. E \& Brinklcy. B.R.J. Cell Biol 91. 95-102 (1981).

B.R.J. Cell Biol 91. 95-102(1981).

Ostergren, G. Hereditas 37, 85-156 (1951).

9. Stern, H. \& Hotta, Y. Phil. Trans. R. Soc. B277, 277-294 (1977).

McCarroll, R.M. \& Fangman. W.L. Cell 54. 505 (1988)

11. Nicklas, R.D.\& Kubai. D.F. Chromosoma 92. 313(1985)

12. Murray, A.W. \& Szostak. J.W. A. Rev: Cell Biol. 1.289 $315(1985)$

Tim Mitchison and Anthony Hyman are in the Department of Pharmacology, University of California, San Francisco, California 94117. USA.

\title{
Geomorphology
}

\section{Hill slopes and hollows}

\section{Mike Kirkby}

THE overall scale of most landscapes is set by the density of river channels. The network of these channels is important in controlling the local relief in an area and the height of flood peaks associated with rain storms. Surprisingly, there is no satisfactory theory to explain channel density, particularly for humid areas. On page 232 of this issue', however, Montgomery and Dietrich address this question and find a strong inverse dependence of stream-head area on hill-slope gradient, which they relate to a model in which landslides initiate channel growth.

The processes that control stream head area are of fundamental importance for hydrology and geomorphology. Models of catchment hydrological response to storms ${ }^{2}$ increasingly distinguish between hill-slope and channel processes, but how the division arises is not clear. Geomorphologists interpret current landscapes in terms of present and past climates and of topographical changes that result as erosion lowers the landscape.

In valley-head hollows, hydrological and sediment-transport effects interact both on hill slopes and in channels. The hydrological interaction is dynamically dependent on the sequence of major

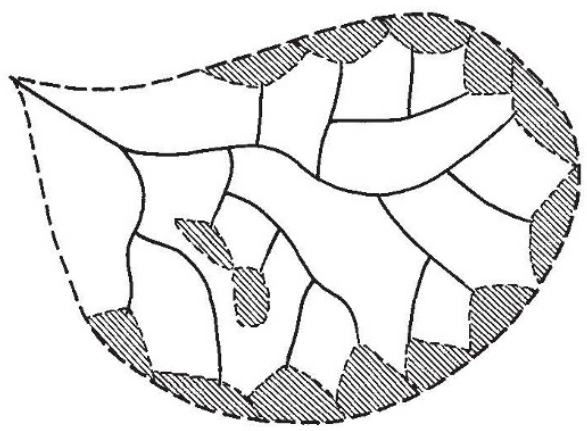

Fig. 1 Schematic map of drainage channels, showing the relationship between channel density, channel spacing and the area drained by each channel head. storms which extend the channels, alternating with quiescent periods during which sediment from the hill slopes tends to refill them. The stream-head and hollow area is thus very sensitive to changes in the climate and land use. Improved understanding could therefore assist environmental reconstructions, over time spans of interest to both archaeologists and Quaternary scientists.

Despite extensive studies $^{3-5}$, starting with that by Horton ${ }^{6}$, channel density dependencies have not been explained. Density, measured as the total length of channel per unit catchment area, ranges from below $1 \mathrm{~km} \mathrm{~km}^{-2}$ in some temperate areas to over $100 \mathrm{~km} \mathrm{~km}^{-2}$ in badland areas. In a channel network, about half of the total length is in the unbranched tributaries (Fig. 1). In areas of high channel density, the area of valley hollow needed to sustain each channel head must be small, and conversely, low-density channels drain large areas.

The work by Montgomery and Dietrich, which was carried out in well-vegetated areas in California and Oregon, shows that there is also a strong inverse dependence of head area on slope for streams with sharp head-cuts (Fig. 2). From their results, the authors suggest that smallscale landslides, initiated under predictable conditions of soil saturation and valley slope, cause the channel growth. The model seems to work well for valley axes steeper than $10^{\circ}-15^{\circ}$.

Other work $^{7 . *}$ has indicated similar relationships, by showing that there are empirical thresholds between gullied and ungullied slopes. Melton had shown that there is a clear link between vegetation cover and the density of drainage channels, at least in the semi-arid zone of the American west. This implies that drainage density falls, and the stream-head area therefore increases in making the transition from sparsely vegetated semi-arid

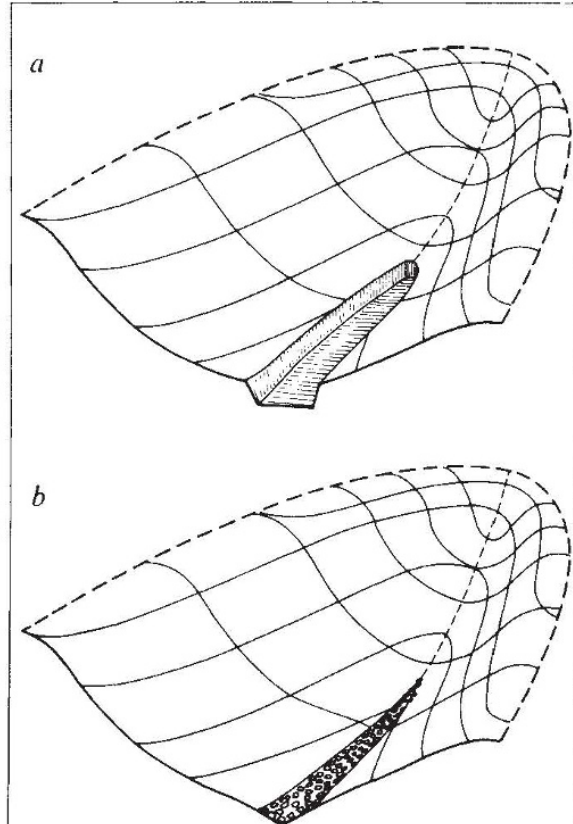

Fig. 2 Types of stream head: $a$, sharp head cut; $b$, gradual.

towards lusher humid areas. Montgomery and Dietrich's' data imply that, in areas which are slightly more humid than Melton's, stream-head area increases gradually from wetter to dryer areas. Although the effect is weak, it provides some of the first good evidence that channel spacing could be forecast for humid areas.

There is, however, at least one difficulty with these data. The stream heads described all show a sharp head-cut where the channel first forms in the valley floor. In many areas, stream heads are much more gradual, as an undoubted channel gradually merges upwards into a hillside hollow (Fig. 2b). This type of gradual stream head is most common where the material in it consists of coarse gravel or boulders, and is found both in humid areas like the Appalachians and in semi-arid areas like south-east Spain. Not only are gradual channel heads hard to locate precisely, but there is some doubt about the applicability of Montgomery and Dietrich's results to this case, because there is no role for landslides in forming a gradual stream head. Indeed, some preliminary data suggest that stream-head area increases with gradient in some cases.

\footnotetext{
1. Montgomery. D.R. \& Dietrich. W.E. Nanure 336. 232-234 (1988).

Hack. J.T. \& Goodlett. J.C. US Geol. Surr. Prof. Pap. 347 (1960)

Melton. M.A. Office nav. Res. Tech. Rep. 11 Project NR $389-42(1987)$

4. Chorley, R.J. \& Morgan. M.A. Geol. Soc. Am. Bull. 73 $17-34(1962)$

Schumm. S. A. Geol. Soc. Am. Bull. 67, 597-6+6 (1956)

6. Horton. R.E Gool Soc Am. Bull 56, 275-370 (1915)

Patton. P.C. \& Schumm. S.A. Geologv 3, 88-90 (1975).

Patton. P.C. \& Schumm. S.A. Geology 3, 88-90(1975)
Graf. W. L. Earth Surface Processes 4, 1-14(1979).

Rodriguez-Iturbe. I. \& Valdez. J. Water Resources Res. 15. $1+(09-1+20(1979)$
}

Mike Kirkby is Professor of Physical Geography at Leeds University, Leeds LS2 9JT, UK. 